\title{
Morphometric Analysis of the Scapula and Their Differences between Females and Males
}

\author{
Análisis Morfométrico de la Escápula y sus Diferencias entre Hombres y Mujeres
}

Ana Camily Oliveira Costa*; Pedro Paulo Feitosa de Albuquerque ${ }^{* *}$; Priscilla Virgínio de Albuquerque**; Belisa Duarte Ribeiro de Oliveira***; Yuri Mateus Lima de Albuquerque* \& Vitor Caiaffo **

OLIVEIRA COSTA, A. C.; FEITOSA DE ALBUQUERQUE, P. P.; DE ALBUQUERQUE, P. V.; RIBEIRO DE OLIVEIRA, B. D.; LIMA DE ALBUQUERQUE, Y. M. \& CAIAFFO, V. Morphometric analysis of the scapula and their differences between females and males. Int. J. Morphol., 34(3):1164-1168, 2016.

SUMMARY: Sexual dimorphism is a key role for forensic anthropology. It allows ascertaining the sex of certain biological discoveries. By postmortem studies it is possible to establish a profile of individuals. This profile allows the identification in cases where bodies are skeletonized. Several bones present dimorphism and have been studied to increase approach for forensic identification. This study morphometrically evaluated the scapula bone and compared the measurements between scapula bone of female and male cadavers. Sixty parts were utilized in this experiment. All cadavers belonged to the Department of Animal Morphology and Physiology of the Federal Rural University of Pernambuco. The scapula bones were photographed and measured through software ImageJ ${ }^{\circledR}$. Eight parameters of measurements were considered: scapula height (SH), distance between basis and spine (DBSp), scapula width (SW), spine width $(\mathrm{SpW})$, acromion-coracoid width (ACW) and scapula body width at 2 (L2), 4 (L4) and 6 (L6) cm of the lower angle. The median

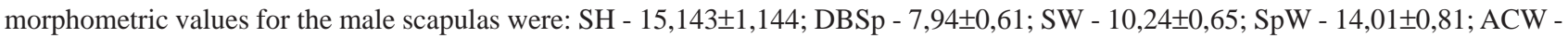
$9,06 \pm 0,58 ; \mathrm{L} 2-4,40 \pm 0,54 ; \mathrm{L} 4-5,51 \pm 0,67$; L6 - 6, 70 $\pm 0,71$. The median morphometric numbers for the female scapulas were: SH -

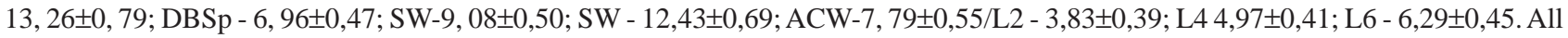
parameters measured showed values significantly higher $(\mathrm{p}<0.05)$ for the male's scapula. The scapula is a bone sexually dimorphic and can potentially be used in forensic investigations. Consequently this data presents the need of more studies utilizing this bone for personal identification in other populations as well. Thus the results of these studies can be useful in cases where other methods are not applicable, increasing the range of options in forensic investigation.

KEY WORDS: Scapula; Morphometry; Sexual dimorphism; Forensic anthropology.

\section{INTRODUCTION}

Throughout human populations skeletons of female and male adults reflect different characteristics in shape and size (Buikstra \& Ubelaker, 1994). The interest in levels and patters of variation of the skeleton features between men and women is related with the analysis of the biodiversity in the past and present of human populations (Physical Anthropology) and in the Forensic Science (Forensic Anthropology). The sex of the person, for the Forensic Anthropology, after specific tests of identity, is essential for personal identification of a body (France, 1998; Cox \& Mays, 2000).

The determination of parameters such as age, stature, ethnicity and sex is primordial in the identification of a biologic discovery. Often the stage of decomposition in which the body is studied is uninformative when some techniques, as DNA test for instance, are utilized. To do so, usually Forensic Anthropology is the only one responsible for the identification of missing people in cases where the remains of the body are skeletonized due to the action of time and/or external agents (Cuenca, 1994).

Because of the incidence of catastrophic events (natural disasters and other mass accidents) a considerable number of cadaveric bodies are not identified. Furthermore an increase in interest of studies in Forensic Anthropology has been noticed towards the identification of ancient populations through bone pieces. These studies intend to

\footnotetext{
* Department of Biology, UFRPE, Recife -PE, Brazil.

** Department of Animal Morphology and Physiology, UFRPE, Recife -PE, Brazil.

*** Department of Physiotherapy, ASCES, Caruaru-PE, Brazil.
} 
make known their way of life from a cultural and social point of view (Casaca \& Rodrigues Ferreira, 2005). The personal identification through sexual dimorphism is proving to be a crucial and effective tool resulting in significant success for the investigator and his analysis (Azevedo, 2008).

In the literature review the morphometric patterns of the mandible, iliac bone, skull, pelvis, scapula bone and other bones are studied, especially in European and American populations (Cunha, 2001). Since it is not always possible to recover the bones from pelvis and skull, in the forensic context other bones of the skeleton have been progressively tested for sexual diagnosis (Bruzek \& Murail, 2006). Among these bones, there is the scapula bone.

The scapula bone is a bone that is frequently obtained in good conditions from skeletal remains (Prescher \& Klümpen, 1995). Accordingly to Hrdlic`ka (1942), the sexual dimorphism in the scapula bone begins to manifest since fetal life. Humphrey (1998) states that after the growth the scapula bone is sexually dimorphic.

It is known that miscegenation in Brazil has been intense and therefore does not have well-defined ethnic and racial patterns. Thus, for identification purposes, morphometric patterns of European Populations, for example, are not applicable for individuals of the Brazilian Population (Rabbi, 2000). This makes the creation of a specific pattern necessary.

The objective of present study is to morphometrically evaluate the scapula bone, and compare these measurements between scapula bones of cadavers in female and male individuals from the Brazilian Population, intending to contribute to the creation of sexual dimorphism patterns for this population.

\section{MATERIAL AND METHOD}

Profile of the sample: We evaluated 60 pairs of scapula bones. Among these 60 pairs, 29 were pairs of scapula bone from males and 31 from females. All subjects were from the Brazilian population and belonged to the Area of Anatomy - Department of Animal Morphology and Physiology from the Universidade Federal Rural de Pernambuco. All cadavers were collected from the Public Cemetery of Santo Amaro (Recife, Pernambuco). The present study was submitted for approval and approved by the Ethics Committee in Research of the University of Pernambuco by protocol number 672.729/2014.
The remains utilized in this study were obtained from individuals buried between December 2009 and March 2012 and all bodies were exhumed between April and May 2014. The age of the individuals at the time of death was between 14 and 98 years old. All remains of bodies under 18 years of age, remains in which the skeleton exhibited signs of trauma or anomalies and remains that were not intact, were discarded.

Registration and measurements: After cleaning and identification the skeletons were photographed utilizing a professional digital camera Canon ${ }^{\circledR}-\bmod 40 \mathrm{D}$, under automatic capture mode. A $50 \mathrm{~mm}$ lens was used, which was set and positioned with the help of a tripod, $61 \mathrm{~cm}$ from the base, in which skeletons would be placed. Each scapula was photographed twice with the back side facing up and the side edge facing up.

Following cleaning and identification, the measurement of the scapula was carried out. For the measurement we used the Image $®$ software version 1:47 and eight parameters of measurement for each one of them (Fig. 1), following the method of Machado et al. (2011): scapula height $(\mathrm{SH})$, distance between basis and spine (DBSp), scapula width (SW), spine width (SpW), acromioncoracoid width (ACW) and scapula body width at 2 (L2), 4 (L4) and 6 (L6) $\mathrm{cm}$ of the lower angle.

1. Scapula Height (SH): maximum distance between the upper and lower angle.

2. Distance between basis and spine (DBSp): maximum distance between the base of the spine and the inner most portion of the glenoid cavity.

3. Scapula Width (SW): maximum distance between the base of the spine and the center of the glenoid cavity.

4. Spine Width ( $\mathrm{SpW}$ ): maximum distance between the base of the spine and the most prominent portion of the acromion.

5. Acromion-Coracoid Width (ACW): maximum distance between the ventral portion of the coracoid process and the most dorsal portion of the acromion.

6. Scapula Body Width at $2 \mathrm{~cm}$ of the lower angle (L2): distance between the medial and lateral edges from the second centimeter height of the scapula.

7. Scapula Body Width at $4 \mathrm{~cm}$ of the lower angle (L4): distance between the medial and lateral edges from the fourth centimeter height of the scapula.

8. Scapula Body Width at $6 \mathrm{~cm}$ of the lower angle (L6): distance between the medial and lateral edges from the sixth centimeter height of the scapula.

Statistical analysis. The mean and standard deviation for each of the measurements performed in the scapula bones 

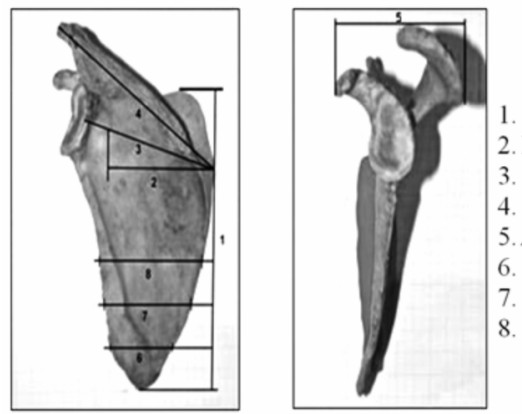

Fig. 1. Morphometric parameters evaluated in male and female scapula. literature for other types of populations (Di Vella et al., 1994; Frutos, 2002; Dabbs, 2010; Scholtz et al., 2010; Machado et al.; Papaioannou et al., 2012).

Studies involving the sexual dimorphism in scapula bones still are few when compared to the number of work involving other bones, such as hip bones for example. Using different methodologies several authors have shown that there are significant differences between several bones, including male and

of each sex was calculated. The data was also submitted to the Kolmogorov-Smirnov test - using the software Minitab version 15 - in order to determine morphometric variables with normal distribution. Following this procedure Student's t-test was used to compare the averages of the data with normal distribution. The average without normal distribution was compared using the Mann-Whitney test. In all cases, a safety margin of $95 \%$ confidence was used.

\section{RESULTS}

The averages obtained from the values (in centimeters) of the measures of the scapula were significantly higher in the population of male individuals, as shown in Table I.

\begin{tabular}{lrrc}
\hline Parameters & \multicolumn{1}{c}{ Male } & \multicolumn{1}{c}{ Female } & \multicolumn{1}{c}{$\boldsymbol{p}$} \\
\hline S.H. & $15,143 \pm 1,144$ & $13,264 \pm 0,797$ & $<0,001^{*}$ \\
D.B.S.p. & $7,944 \pm 0,615$ & $6,96 \pm 0,478$ & $<0,001^{*}$ \\
S.W. & $10,243 \pm 0,658$ & $9,081 \pm 0,504$ & $<0,001^{*}$ \\
Sp.W. & $14,012 \pm 0,813$ & $12,433 \pm 0,695$ & $<0,001^{*}$ \\
A.C.W. & $9,069 \pm 0,581$ & $7,79 \pm 0,553$ & $<0,001^{*}$ \\
L2 & $4,408 \pm 0,546$ & $3,835 \pm 0,390$ & $<0,001^{*}$ \\
L4 & $5,511 \pm 0,676$ & $4,979 \pm 0,415$ & $<0,001^{*}$ \\
L6 & $6,702 \pm 0,717$ & $6,292 \pm 0,451$ & $<0,05^{*}$ \\
\hline
\end{tabular}

* Statistical difference between the scapula bone of the male and female. T-Student test.

** Statistical difference between the scapula bone of the male and female. Mann-Whitney test.

\section{DISCUSSION}

The present study demonstrated higher values of measurements of male compared to female scapula bones. These results corroborate with data already reported in the female scapula bones (Di Vella et al.; Frutos; Dabbs; Scholtz et al.; Machado et al.; Papaioannou et al.).

Machado et al. using the same morphometric parameters adopted in this study have shown a significant difference between male and female individuals in Europeans with Hispanic descent. These authors obtained values that assert that the less accurate measure between the scapula bones of the two sexes was the width of the spine, while our study found that the most significant difference was between the heights of the scapula. The measure showing the least difference between sexes was the width of the body of the scapula to $6 \mathrm{~cm}$ from the bottom angle in both studies.

Machado et al. developed highly reliable discriminant equations for forensic applicability with the degree of confidence greater than $85 \%$ for all measurements, reaching up to $95.5 \%$ efficiency. Bainbridge \& Genoese (1956) were the first to use the full scapula as an indicator of gender differences, calculating equations whose reliability was between 84.20 and $99.87 \%$, matching 11 morphometric variables. Pimienta (2000) reached a successful $90 \%$ reliability for the differentiation between sexes, combining the variables of the maximum length and width of the glenoid cavity. However, this author did not take into account racial influences of individuals, which may have overestimated the results. The present study did not take into account racial influences of individuals because of the large miscegenation of the Brazilian population.

Also developing discriminant equations, Papaioannou et al. were able to obtain up to $95.9 \%$ accuracy in the given equation which used the width of the spine beyond the width of the glenoid cavity, as variables for sex determination. These authors evaluating 147 scapula bones of Greek population individuals, based on the study of Charisi et al. (2011), consider that the high protein diet for the Greek male individuals in ancient times, because of the sexual division of labor, could be one of the reasons for male bones exceeding the dimensions of the female. 
This paper considers that the reason for the shoulder scapula bones of men are generally larger than the female could be due to the physical effort performed by male ancestors. This justification was also adopted by Scholtz et $a l$. This fact is due to the greater development of the muscles of the upper limbs of male individuals, so that bone growth accompanies this structure to ensure the support of the muscle tissue attached. Hrdlic $`$ ka concluded that scapular growth is almost entirely governed by the development of the muscles.

Because the bone structure follow the development of muscles, Machado et al. give a sexual dimorphism all bones of the skeleton. Therefore, many bones show a gender difference. For example the skull bones (Almeida \& Costa, 1977; da Silva, 1997; Delwing, 2013), the long bones (Cardoso, 2001; Francesquini, 2007), the bones of pelvis (Rabbi) among others.

\section{CONCLUSION}

The scapula is a sexually dimorphic bone with high potential for use in forensic purposes. The measurements performed were effective for gender identification also in a mixed population. Another advantage is to contribute to the formation, if possible, of a standard for the Brazilian population.

Therefore, these data reflect the importance that more studies need to be conducted using this bone as a tool for personal identification. This way the measurements of this bone can be useful in cases where other methods are not applicable, increasing the range of options of forensic investigation teams.

OLIVEIRA COSTA, A. C.; FEITOSA DE ALBUQUERQUE, P. P.; DE ALBUQUERQUE, P. V.; RIBEIRO DE OLIVEIRA, B. D.; LIMA DE ALBUQUERQUE, Y. M. \& CAIAFFO, V. Análisis morfométrico de la escápula y sus diferencias entre hombres y mujeres. Int. J. Morphol., 34(3):1164-1168, 2016.

RESUMEN: El dimorfismo sexual es una función clave para la antropología forense. Permite determinar el sexo de ciertos descubrimientos biológicos. Para estudios post mortem, es posible establecer el perfil de los individuos. Este perfil permite la identificación de los cuerpos en el caso que sean solo esqueletos. Varios huesos presentaron dimorfismo y fueron estudiados para aumentar el enfoque en la identificación forense. Este estudio evaluó morfométricamente la escápula y se compararon las mediciones entre la escápula de cadáveres femeninos y masculinos. Se utilizaron 60 piezas en esta investigación. Todos los cadáveres pertenecían al Departamento de Morfología y Fisiología Animal de la Universidad Federal Rural de Pernambuco. Los huesos fueron fotografiados y se midieron a través del software ImageJ®. Se consideraron ocho parámetros de las mediciones: altura de la escápula (SH), distancia entre la columna vertebral y la cavidad glenoidea (DBSP), ancho de la escápula (SW), ancho de la columna vertebral (SpW), distancia entre acromion y proceso coracoides (ACW) y ancho del cuerpo de la escápula a 2 (L2), 4 (L4) y 6 (L6) cm del ángulo inferior de la escápula. Los valores morfométricos de la mediana para las escápulas de los hombres fueron: SH - 15.143 \pm 1.144 ; DBSP - 7,94 $\pm 0,61$; SW - 10,24 $\pm 0,65$;

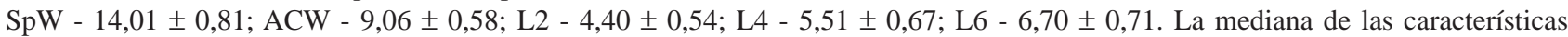
morfométricas de las escápulas de las mujeres fueron: $\mathrm{SH}-13,26 \pm 0,79$; DBSP - 6,96 $\pm 0,47$; SW - 9,08 $\pm 0,50$; SW - 12,43 $\pm 0,69$; ACW $-7,79 \pm 0,55$ / L2 - 3,83 \pm 0,39; L4 4,97 $\pm 0,41$; L6 - 6,29 \pm 0,45. Todos los parámetros medidos mostraron valores significativamente mayores $(\mathrm{p}<0,05)$ para la escápula de los hombres. La escápula es un hueso que presenta dimorfismo sexual y puede ser utilizado en investigaciones forenses. En consecuencia, estos datos sugieren la necesidad de realizar más estudios de este hueso para la identificación en otras poblaciones. Los resultados de este estudio pueden ser útiles en aquellos casos en los que otros métodos no puedan aplicarse, debido a que presentan mayores opciones para la investigación forense.

PALABRAS CLAVE: Escápula; Morfometría; Dimorfismo sexual; Antropología forense.

\section{REFERENCES}

Almeida, A. J. \& Costa, J. B. O. Lições de Medicina Legal. 14ª ed. São Paulo, Companhia Editora Nacional, 1977.

Azevedo, J. M. C. A. A Eficácia dos Métodos de Diagnose Sexual em Antropologia Forense. Tese Mestrado em Medicina Legal e Ciências Forenses. Lisboa, Faculdade de Medicina, Universidade de Lisboa, 2008.

Bainbridge, D. \& Genoves, S. T. A study of sex differences in the scapula. J. R. Anthropol. Inst., 86:109-34, 1956.
Bruzek, J. \& Murail, P. Methodology and Reliability of Sex Determination from the Skeleton. In: Schmitt, A.; Cunha, E. \& Pinheiro, J. (Eds.). Forensic Anthropology and Medicine: Complementary Sciences from Recovery to Cause of Death. Totowa, Humana Press, 2006. pp.225-42.

Buikstra, J. E. \& Ubelaker, D. H. Standards for Data Collection from Human Skeletal Remains: Proceedings of a Seminar at the Field Museum of Natural History (Arkansas Archeological Report Research Series, Book 45). Fayetteville, Arkansas Archeological Survey, 1994. 
Cardoso, H. F. V. Dimorfismo Sexual na Estatura, Dimensões e Proporções dos Ossos Longos dos Membros: O Caso de Uma Amostra Portuguesa dos Séculos XIX-XX. Tese Mestrado em Evolução Humana. Coimbra, Faculdade de Ciências e Tecnologia, Universidade de Coimbra, 2001.

Casaca, C. \& Rodrigues Ferreira, F. E. Necrópole da Sé Silves. Arqueol. Hist., 56-57:103-110, 2005.

Charisi, D.; Eliopoulos, C.; Vanna, V.; Koilias, C. G. \& Manolis, S. K. Sexual dimorphism of the arm bones in a modern greek population. J. Forensic Sci., 56(1):10-8, 2011.

Cox, M. \& Mays, S. Human Osteology in Archaeology and Forensic Science. London, Greenwich Medical Media, 2000. pp.11729.

Cuenca, J. V. R. Introducción a la Antropología Forense. Análisis e Identificación de Restos Óseos Humanos. Bogotá, Universidad Nacional de Colombia, 1994.

Cunha, E. A Paleopatologia como Fator de Individualização em Antropologia Forense. Lição de síntese. Provas de agregação. Coimbra, Universidade de Coimbra, 2001.

da Silva, M. Compêndio de Odontologia Legal. São Paulo, Guanabara Koogan, 1997.

Dabbs, G. Sex determination using the scapula in New Kingdom skeletons from Tell El-Amarna. Homo., 61(6):413-20, 2010.

Delwing, F. Análise do Dimorfismo Sexual em Adultos através de Medidas Cranianas. Tese Mestrado em Biologia Buco-dental. Piracicaba, Faculdade de Odontologia de Piracicaba, Universidade Estadual de Campinas, 2013.

Di Vella, G.; Campobasso, C. P.; Dragone, M. \& Introna, F. Jr. Skeletal sex determination by scapular measurements. Boll. Soc. Ital. Biol. Sper., 70(12):299-305, 1994.

France, D. L. Observation and Metric Analysis of Sex in the Skeleton. In: Reichs, K. T. (Ed.). Forensic Osteology: Advances in the Identification of Human Remains. Springfield, Charles C. Thomas Publisher, 1998. pp.163-86.

Francesquini, M. A. Avaliação da Medida de Comprimento de Ossos Longos de Individuos Adultos quanto ao Dimorfismo Sexual. Tese Doutorado em Radiologia Odontológica. Piracicaba, Faculdade de Odontologia de Piracicaba, Universidade Estadual de Campinas, 2007.

Frutos, L. R. Determination of sex from the clavicle and scapula in a Guatemalan contemporary rural indigenous population. Am. J. Forensic Med. Pathol., 23(3):284-8, 2002.

Hrdlic $^{`} \mathrm{ka}$, A. The adult scapula. Additional observations and measurements. Am. J. Phys. Anthropol., 29(3):363-415, 1942.
Humphrey, L. T. Growth patterns in the modern human skeleton. Am. J. Phys.Anthropol., 105(1):57-72, 1998.

Machado, M. D.; Corona, S. E. \& Arredondo, A. C. Determinación del sexo a partir de la escápula en europoides de ascendencia hispánica. Rev. Esp. Antropol. Fís., 32:36-42, 2011.

Papaioannou, V. A.; Kranioti, E. F.; Joveneaux, P.; Nathena, D. \& Michalodimitrakis, M. Sexual dimorphism of the scapula and the clavicle in a contemporary Greek population: applications in forensic identification. Forensic Sci. Int., 217(1-3):231.e17, 2012.

Pimienta, M. M. Dimorfismo Sexual en una Población Mexicana. Nuevas Fórmulas para la Determinación del Sexo en el Esqueleto Postcraneal. Tesis de Doctorado. Granada, Universidad de Granada, 2000.

Prescher, A. \& Klümpen, T. Does the area of the glenoid cavity of the scapula show sexual dimorphism? J. Anat., 186 (Pt. 1):2236, 1995 .

Rabbi, R. Determinação do Sexo atraves de Medições em Ossos da Pelve de Esqueletos Humanos. Tese Mestrado em Odontologia Legal e Deontologia. Piracicaba, Faculdade de Odontologia de Piracicaba, Universidade Estadual de Campinas, 2000.

Scholtz, Y.; Steyn, M. \& Pretorius, E. A geometric morphometric study into the sexual dimorphism of the human scapula. Homo, 61(4):253-70, 2010.

Corresponding to:

Vitor Caiaffo

Department of Animal Morphology and Physiology

UFRPE

Recife -PE

Brazil.

E-mail: vitor.caaufpe@gmail.com

Received:14-10-2015

Accepted:07-07-2106 